\title{
THE INVESTIGATION OF THE EFFECTS OF ECCENTRIC EXERCISES ON SOME MOTORIC CHARACTERISTICS OF YOUTH SOCCER PLAYERS
}

\author{
Atakan ÇĂGLAYAN ${ }^{1}$, İbrahim ERDEMİR ${ }^{2}$ \\ ${ }^{1}$ İstanbul Gedik Üniversitesi, Spor Bilimleri Fakültesi, İstanbul/Türkiye \\ ${ }^{2}$ Balıkesir Üniversitesi, Beden Eğitimi ve Spor Yüksekokulu. Balıkesir/Türkiye
}

\begin{abstract}
There are various training programs to improve sportive performance so that soccer-specific technical skills can be realized more easily. The aim of the study is to examine the effect of the training program that including eccentric and concentric contractions on strength, balance and agility in young soccer players. 26 male soccer players (age: $12 \pm 1.6 y e a r s)$ who played in an amateur sport club participated voluntarily to the study. Pretests were taken before the training program. There were two groups of athletes; the experimental group (EG; $\mathrm{n}=13$ ) were applied exercises that including eccentric and concentric contractions while Control Group players $(\mathrm{CG} ; \mathrm{n}=13)$ continued their traditional soccer trainings. The post-tests were taken at the end of the 8-week training program. Pre- and post-test included flamingo balance test (FB), y balance test (YB), standing long jump test (SLJ), vertical jump test (VJ) and Illinois test (IT). When the obtained data were examined, EG athletes were statistically improved in all the parameters in the pre-, and post-test $(\mathrm{p}<0.05)$ and no statistically significant difference was seen in the CG athletes ( $p>0.05$ ). When the differences between the groups were examined, it was statistically significant in the $y$ balance test $(p<0.05 ; p=0.032)$ and Illinois test $(p<0.05 ; p=0.022)$ parameters for respectively determining the dynamic balance and agility of EG athletes compared to CG athletes $(p<0.05)$. As a conclusion, eccentric and concentric contraction exercises performed before soccer specific training programs seem to be effective on dynamic balance and agility. It is also thought that such training programs could improve the performance of the athletes, and prevent them from lower extremity injuries.
\end{abstract}

Key words: soccer, balance, agility, concentric contraction, eccentric contraction

\section{EKSANTRIKK EGZERSIZLERIN GENÇ FUTBOLCULARIN BAZI MOTORIK ÖZELLIKLERİ ÜZERINE ETKILERININ İNCELENMESİ}

Öz: Sportif performansı arttırmak için çeşitli antrenman programları bulunmaktadır böylelikle futbola özgü teknik beceriler daha kolay gerçekleştirilebilir. Bu çalışmanın amacı, genç futbolcularda eksantrik ve konsantrik kasılmalar içeren antrenman programının kuvvet, denge ve çeviklik üzerine etkisini incelemektir. Çalışmaya, bir amatör spor kulübünde oynayan 26 erkek futbolcu (yaş: $12 \pm 1,6$ yıl) gönüllü olarak katılmış̧tr. Antrenman programından önce ön testler yapılmış ve sporcular iki gruba ayrılmıştı; Çalışma Grubuna (EG; $n=13$ ) eksantrik ve konsantrik kasılmalar içeren egzersizler uygulanırken, Kontrol Grubu oyuncuları $(\mathrm{CG} ; \mathrm{n}=13)$ ise geleneksel futbol antrenmanlarına devam etmişlerdir. Son testler 8 haftalık antrenman programının sonunda alınmıştır. Ön ve son testlerde; flamingo denge testi (FB), y denge testi (YB), durarak uzun atlama testi (SLJ), dikey atlama testi (VJ) ve Illinois testi (IT) uygulanmıştır. Elde edilen veriler incelendiğinde EG sporcuları, grup içi ön-son testlerinde tüm parametrelerde istatistiksel olarak gelişim tespit edilirken $(\mathrm{p}<0.05)$, CG sporcularında istatistiksel olarak anlamlı bir fark görülmemiştir ( $\mathrm{p}>0.05$ ). Gruplar arasındaki farklar incelendiğinde ise, EG sporcuları CG sporcuları ile karşıllaştırıldığında dinamik denge ve çeviklik özelliklerini belirlemek için uygulanan y denge testi $(p<0.05 ; p=0.032)$ ve Illinois testi $(p<0.05 ; p=0.022)$ parametrelerinde istatistiksel olarak anlamlı gelişim görülmüştür $(\mathrm{p}<0,05)$. Sonuç olarak, futbola özgü antrenman programlarından önce uygulanan eksantrik ve konsantrik kasılma egzersizlerinin dinamik denge ve çeviklik üzerinde etkili olduğu görülmektedir. Ayrıca, bu tür antrenman programlarının sporcuların performansını artırabileceği ve oyuncuları alt ekstremite yaralanmalarından koruyabileceği düşünülmektedir.

Anahtar Kelimeler: futbol, denge, çeviklik, konsantrik kasılma, eksantrik kasılma 


\section{INTRODUCTION}

Soccer is the most popular game in the world with millions of participants and fans. It is the most central sports in Asia, Europe, Africa and South America. It is the mostly researched team sports because of its popularity and financial attraction (Kayıtken, Yücel ve Dinç, 2012). That the technical skills pertain to soccer are performed in a qualified way depends on the biomotor features of the soccer players. The development of motor skills such as the endurance, strength, speed, agility, flexibility, balance and skill of a player can be provided through trainings pertain to that sports branch (Karacabey, 2013). Children at this age, because of their excellent motoric learning conditions, it is necessary to bring as many movement experiences as possible in the sport. From a physiological point of view, it is seen that motoric maturity is provided in this period. In this period, it may be seen as the reason for the high qualities of motor learning (Muratl 2003). In this period when sportive activities play an active role in the physical development of children (Soğat, 2007), significant changes in the psychological field, rapid growth, rapid activity of hormones and maturation are observed. (Özer ve Özer, 2007). It is useful to know the anatomical, physiological, psychological and motoric characteristics of the patients at certain ages, starting from the earliest possible age and performing the necessary exercises. It has been reported that the trainings which are made conscious have a positive effect on the development or even provide a social personality while providing the physical and motor development of the child (Ağaoğlu ve ark, 2008). As much as the exercise in children itself is important in the dosage of these movements (Akgün, 1982). It was observed that moderate intensity training had a positive effect on children's growth (Erikson, 1972). However, the important thing about the health issue is that children are not given early start to traumatic sports by keeping their training under control. (Ağaoğlu ve ark, 2008).

Eccentric contraction which is applied in the presented study is a type of contraction with which the length of muscles grows. In eccentric exercises, contraction muscle is grown by force; it shortens in concentric exercises. Whereas the concentric contractions start the movement, the eccentric contractions make them slow down and stop. The aim here is the growth in the length of muscle which occurs as a result of the muscle's surpassing its skill of actively displaying endurance against a load which is applied externally (Sevim, 2007). An important feature of eccentric exercise is that untrained participants' muscles tighten up and ache day by day because of the damage done in the muscle fibers. Besides the damage in muscle fibers, there is evidence that there is deformation in muscle spindles and proprioceptors. However, it is revealed that muscles display adaptation and get less damaged in the second period of exercises. As the cause of this adaptation, increase in the number of sarcomeres is addressed. This contributes to the grown of the length of muscles in an optimum level during the active tension. This situation reports that eccentric exercises can provide with the opportunity to protect muscles from greater injuries (Proske ve Morgan, 2001). Recently, many studies supporting the ideas that touch upon the importance of eccentric strength production capacity of muscles and that it is necessary to increase this capacity with eccentric strength training methods using new technology especially in protecting from hamstring injuries (Işık ve Ünlü, 2017). In addition to that, eccentric training can be used in order to obtain important strength and mass acquisition. Also, it can play a key role in getting into the next level and in reducing the number of sustained injuries (Şendil, 2008).

In order to develop sportive skill and to prevent injuries, one of the fundamental factors is the feature of balance which is defined as an effective factor in developing motor skills (Erkmen, Suveren, Göktepe ve Yazıcıoğlu, 2007). Along with this, the feature of agility which is a very significant parameter in soccer is defined as the skill of changing direction fast with the 
cooperation of force, strength and neuromuscular coordination without losing balance (Turner, 2011).

There are various training programs towards developing sportive performance in the literature (Blimkie and Sane 1988, Wilson ve ark, 1993). In the presented study, it is aimed to examine the effect of the training program that including eccentric and concentric contractions on strength, balance and agility in young soccer players.

\section{MATERIAL AND METHODS}

Participants: In the EG, there are 26 male soccer players playing in two different amateur sports club in Turkey. 13 male athletes continuing their trainings in an amateur sports club form the training group $(\mathrm{EG}$; age $=12 \pm 1.4), 13$ male athletes continuing their trainings in another amateur sports club form the $\mathrm{CG}(\mathrm{CG}$; age $=12 \pm 1.8)$. While $\mathrm{EG}$ received eccentric training program (Table 3), Control Group (CG) continued their traditional soccer trainings. The study consists of pretest, eight-week training program and post-test. EG and CG athletes were jogging for 10 minutes before each session in the training program. After that, they made dynamic warming and dynamic stretching for the lower extremity. The Eccentric Training program applied to EG athletes lasted about half an hour. In the training, 7 different drills were made as 8 sets of 8 repeats. There was a two minute rest between the sets. After the eccentric exercises, athletes continued to practice classical football. $5 \mathrm{~min}$ jog in the cooling section followed by static stretching.

Table 3. Training Program

\begin{tabular}{|c|c|c|}
\hline Movements & 1-4 Week & 5-8 Week \\
\hline Eccentric Split Squat & 8 rep $x \overline{3 \text { sets }}$ & \\
\hline Eccentric Toe Squat & 8 rep $x 3$ sets & \\
\hline Eccentric lunge & 8 rep x 3 sets & \\
\hline Slider side lunge & 8 rep $x 3$ sets & 8 rep $x 3$ sets \\
\hline Glute bridge and curl & 8 rep $x 3$ sets & 8 rep x 3 sets \\
\hline Eccentric Glute Bridge & 8 rep x 3 sets & 8 rep $x 3$ sets \\
\hline Eccentric Step Down & 8 rep x 3 sets & 8 rep x 3 sets \\
\hline Eccentric Balance Lunge & & 8 rep $x 3$ sets \\
\hline Eccentric Deadlift & & 8 rep $x 3$ sets \\
\hline Single Leg Deadlift & & 8 rep $\times 3$ sets \\
\hline
\end{tabular}

$Y$ Balance Test: The participants were asked to stay on one foot which is their dominant foot and to push the mechanism as far as they could with their loose foot towards anterior, posteromedial and posterolateral directions. The test was done in three successful trials to each direction on the dominant foot, and the maximum obtained distances were measured in $\mathrm{cm}$ and the most successful results were recorded (Johnston, O'Reillya, Coughlanc ve Caulfielda, 2017; Hammami, Granacher, Makhlouf, Behm ve Chaouachi, 2016). During the lounges, the situation in which the foot did not touch the floor was accepted as invalid. Score Analysis: the comparison of leg length and total stretching distance is calculated as follows: three stretching directions are summed, it is divided to the length of leg $(\mathrm{cm})$ times three and the result is multiplied with 100 (Rosch ve ark., 2000). Leg length: when the individual lifts his/her hip on the platform, the researcher passively makes the legs straight in order to equalize the pelvis. The right leg of the individual is measured from the lower edge of anterior superior iliac until the furthest part of medial malleol (Plisky, Rauh, Kaminski ve Underwood, 2006). 
Vertical Jump Test: The participants were asked to jump as high as they can on their both feet by permitting to the swinging of arms and legs. The measurements were done in three repetitions and the highest score was recorded in cm (Harman ve Garhammer, 2008).

Standing Long Jump: A starting-line was drawn on a flat floor and a tape measure was placed from starting-line towards forwards. The athletes were asked to place the tips of their two toes right behind of the predetermined line. The athletes waited their arms paralleled to the floor and their knees; their knees were bent and they were asked to jump as much further as they can by swinging in a fast way using their arms and legs. The distance of jump was measured by looking at the distance between their beginning point and the landing with their ankles. The test was repeated three times and the best scores were recorded in $\mathrm{cm}$ (Harman ve Garhammer, 2008).

Flamingo Balance Test: The balance measurements of the athletes were made with Flamingo balance device. The participants tried to stay in balance on their dominant foot during oneminute period on a wooden balance beam which $50 \mathrm{~cm}$ long, $4 \mathrm{~cm}$ high and $3 \mathrm{~cm}$ wide. When the balance is disturbed (if the participant lets go of his/her foot while holding it, falls from the wooden beam, touches the floor with any of his/her part of body and etc.) the time was stopped. When the subject regained his/her balance after getting on the balance beam, the time started to continue. The test continued in this way for one-minute period. When the period was completed, the attempt of regaining balance (after the fall) of the EG group was counted and the number was recorded when the test was finished and the period of one minute was completed (Deforche ve ark.,2012).

Illinois Agility Test: The Illinois test track which was used so as to measure the agility is $5 \mathrm{~m}$ wide and $10 \mathrm{~m}$ long and consists of three cones which are placed on a straight line in the middle part. The track was set on a synthetic lawn soccer field. The test consists of 40 meters long running and 20 meters slalom running among cones which includes $180^{\circ}$ turns for each 20 meters. Before the test started, the athletes had received the necessary explanations; and afterwards, they were allowed to have a trial. After the trials, the athletes were asked to do warm-up and stretching exercises for 5-6 minutes in a low rate. The athletes had a start from the starting-line of the test track. The duration of finishing the track was recorded in seconds. Each athlete took the test twice and their best score was recorded. Between every trial, the athletes received 180 seconds to recover (Hazır, Mahir ve Açıkada, 2010).

Data Analysis: The data obtained in the tests were analyzed with SPSS 21.0 program. In order to determine if the data show a normal distribution or not, Shapiro-Wilk test was done and it was determined that they do not show a normal distribution. In determining the change before and after the trainings of EG and CGs, Wilcoxon test was used; and in comparison, of the two groups, Man-Whitney U test was applied. The statistical significance level was accepted as 0.05 $(\mathrm{p}<0.05)$.

\section{RESULTS}

As a result of our study, the descriptive statistics, intra-group comparisons and inter-group comparisons of EG and CG players were completed in accordance with pre-and post-test measurements; and the following findings were obtained. The descriptive data of the EG and CGs have found that; The mean of the height of EG group was found $1.56 \pm 0.08 \mathrm{~m}$. the weight mean was found $48.57 \pm 8.86 \mathrm{~kg}$, body-mass index mean was found $19.5 \pm 2.42 \mathrm{~kg} / \mathrm{m} 2$. Meanwhile, the mean of the height of CG was found $1.54 \pm 0.08 \mathrm{~m}$, the weight mean was found $47.83 \pm 8.36 \mathrm{~kg}$, and their body-mass index mean was found $19.88 \pm 2.51 \mathrm{~kg} / \mathrm{m} 2$. 
Table 1. EG / CGs - Intra-group Comparison of Pre- and Post-Test Data

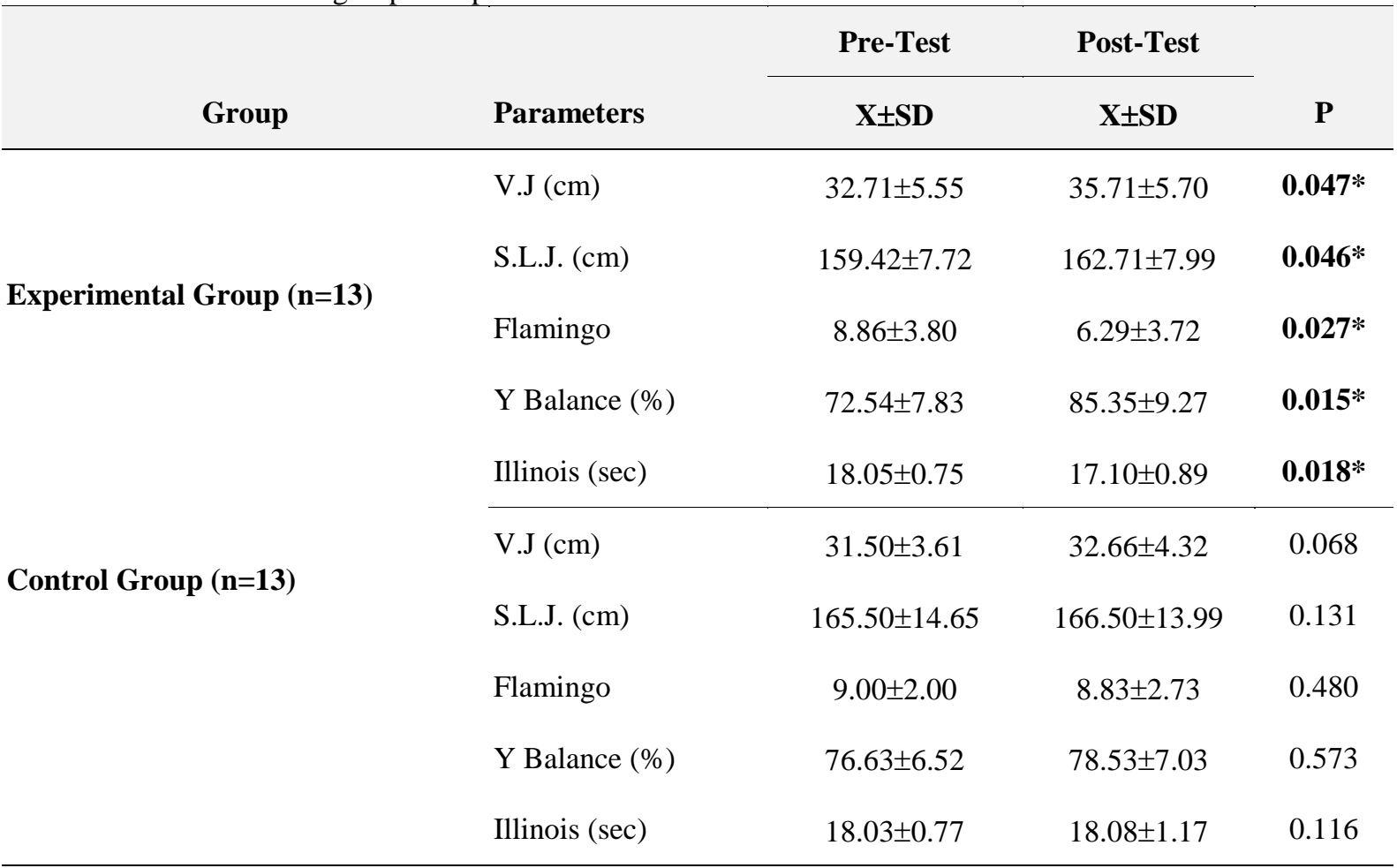

BMI = Body Mass Index, V.J. = Vertical Jump, S.L.J. = Standing Long Jump, $\mathrm{p}=$ Statistical Difference $* \mathrm{p}<0.05$

When the pre- and post-test values of the EG group is examined, it is determined that there is a difference on the significance level in the comparison of vertical jump and standing long jump which are strength tests, of flamingo and y balance tests which are balance tests and of Illinois test which is an agility test $(\mathrm{p}<0.05)$.

When the pre- and post-test values of the CG is examined, no significant difference is found in strength, balance or agility tests $(\mathrm{p}>0.05)$.

Table 2. Intergroup Comparisons of EG (N=13)/ CGs' $(\mathrm{N}=13)$ Pre- and Post-test Change Data

\begin{tabular}{|c|c|c|c|}
\hline \multirow[b]{2}{*}{ Parameters } & \multirow[b]{2}{*}{ Group } & \multicolumn{2}{|c|}{$\mathbf{p}$} \\
\hline & & Pre & Difference \\
\hline \multirow{2}{*}{ Vertical Jump (cm) } & EG & \multirow{2}{*}{0.666} & \multirow{2}{*}{0.351} \\
\hline & CG & & \\
\hline \multirow{2}{*}{ Standing Long Jump (cm) } & $\mathrm{EG}$ & \multirow{2}{*}{0.474} & \multirow{2}{*}{0.830} \\
\hline & $\mathrm{CG}$ & & \\
\hline \multirow{2}{*}{ Flamingo } & EG & \multirow{2}{*}{0.885} & \multirow{2}{*}{0.128} \\
\hline & $\mathrm{CG}$ & & \\
\hline \multirow{2}{*}{ Y Balance $(\%)$} & EG & \multirow{2}{*}{0.668} & \multirow{2}{*}{$0.032 *$} \\
\hline & CG & & \\
\hline \multirow{2}{*}{ Illinois (sec) } & EG & \multirow{2}{*}{1.00} & \multirow{2}{*}{$0.022 *$} \\
\hline & $\mathrm{CG}$ & & \\
\hline
\end{tabular}

When the pre- and post-test values of the EG and CG players are considered, there is no difference between the two groups in the pre-tests $(p>0.05)$. When the difference and change 
after the post-test are examined, there are statistically significant differences $(\mathrm{p}<0.05)$ in favor of EG athletes in terms of $y$ balance $(\mathrm{p}=0.032)$ and agility $(\mathrm{p}=0.022)$ parameters.

\section{DISCUSSION AND CONCLUSION}

That the obtained information about the effective strength development in reaching a good sportive performance in competitive sports provides with advantages for the athletes and trainers. In sports branches such as soccer which includes features such as strength, speed, agility, endurance and balance, the use of scientific methods is important. It is especially important to pay attention while planning strength development which plays an important role in enabling all skills. Before starting strength, trainings which are soccer related, concentric and eccentric strength trainings can be applied in children and young people.

The movements that are performed in many sports types include the combination of concentric and eccentric moves (Dickinson ve ark., 2000). During eccentric movements, the muscletendon system is stretched and thus mechanical energy is absorbed (Lindstedt, LaStayo ve Reich, 2001). This absorbed energy can be distributed as heat. In this case, the muscle serves as shock absorber in such situations as running downhill, skiing or fall after jumping. In addition, the energy which is absorbed in fast and cyclic movements is temporarily stocked as elastic energy and later it is renewed during a short-term contraction (Vogt ve Hoppeler, 2013). Depending on the eccentric and concentric contraction time, fast and slow, short span-stretching cycle can be distinguished (Schmidtbleicher, 1992). For example, slow short stretching cycle can be seen during jumps in basketball and volleyball when there are small angular slips and when the contiguity on the floor is less than 0.25 seconds. An important time element exists in the function of short stretch cycle; if the phase between eccentric and concentric is long, elastic energy disappears as heat (Vogt ve Hoppeler, 2013).

As a result of the eccentric exercises applied in this study, it can be seen that young soccer players displayed statistical developments $(p<0.05)$ in parameters such as strength $(p=0.47)$. force $(p=0.46)$, static balance $(p=0.27)$, dynamic balance $(p=0.15)$ and agility $(p=0.18)$. Nonetheless, no change has been determined in the young soccer players who continue their regular training program $(\mathrm{p}>0.05)$. In the literature, there are studies reporting that eccentric exercises stimulate different muscle activation patterns and they have a great charging potential by consuming a very low level of energy which supports our study (Vogt ve Hoppeler, 2013). It is reported that eccentric training models not only provide with the coordination during the exercise, but also can speed up the maximal muscular strength development or at least optimize it. Therefore, it is thought that the performance in many sports branch can be developed and possible injuries can be prevented by integrating eccentric based training protocols into strength and condition programs (Cowell, Cronin ve Brughelli, 2012; LaStayo ve ark., 2003).

When the change differences between groups are analyzed, the dynamic balance $(\mathrm{p}=0.032)$ and agility $(\mathrm{p}=0.022)$ measurements of the young soccer players who are in EG show a statistically significant change when compared to the young soccer players who are in $\mathrm{CG}(\mathrm{p}<0.05)$. Rapid and strong eccentric contraction and strong concentric contractions coming right (Malisoux, Francaux and Nielens (2006) and after that, the improvements in the stretching and contraction cycle can be effective on the development of balance. There are publications in the literature stating that agility develops after plyometrical practices where this kind of contractions occur (Meylan ve Malatesta, 2009; Thomas, French ve Hayes, 2009). The results revealed in our study are in accordance with the literature. When it is considered that the soccer players perform the actions such as ball control, pass, and kick with their dominant leg, it is seen that their non- 
dominant leg play the role of balance; however, according to the y balance test data of the eccentric exercises applied in the presented study which measures especially the dynamic balance, its effect on dominant leg has been analyzed and it is seen that EG has statistically significant development $(\mathrm{p}<0,05)$. When the non-dominant leg must be used in the complicated positions in soccer, the development in the dominant leg which will play the role of balance in this case is important. In this regard, it is thought that eccentric trainings should be integrated into training programs.

In order to obtain a successful performance in sports branches and in order to jump faster and higher, trainings that develop the feature of jump and strength of leg are needed. In the present study, after the training program which is applied with the short tension cycle. it has been expected that explosive power and leg strength should improve. However. although there is a statistically significant development in EG athletes no difference has been found between the groups ( $p>0.05$ ). In contrast to our study, Hindistan et.al, (1999) stated in their study that was carried out in that eccentric and concentric trainings developed explosive power and leg strength. Similar results were seen in standing long jump.

As a result, before starting special strength trainings in young soccer player, it is estimated that training programs that include eccentric and concentric contractions applied in play-like forms can provide with positive developments in the performances of the young athletes by improving features such as strength, balance and agility and can prevent possible future injuries as well.

\section{REFERENCES}

Ağaoğlu S.A., Taşmektepligil Y., Aksoy Y., Hazar F. (2008) Yaz spor okullarına katılan gençlerin yaş gruplarına göre fiziksel ve teknik gelişimlerinin analizi. Spormetre Beden Eğitimi ve Spor Bilimleri Dergisi, VI (3), 159-166.

Akgün N., (1982). Egzersiz Fizyolojisi, Ege Üniversitesi Matbaas1, s.221, İzmir.

Blimkie C.J.R., Sale D.G. (1998). Strength development and trainability during childhood. In: Pediatric Anaerobic Performance. E Van Praagh (ed.). Champaign, Illinois: Human Kinetics, p, 193-224

Cowell J.F., Cronin J., Brughelli M. (2012). Eccentric muscle actions and how the strength and conditioning specialist might use them for a variety of purposes. Strength Cond J, 34, 33-48

Deforche B., Oyeyemi A.L., Adegoke B.O., Oyeyemi A.Y., Bourdeaudhuij I., Sallis J.F. (2012). Environmental factors associated with overweight among adults in nigeria. Int J Behav Nutr Phys Act, 9, 32

Dickinson M.H., Farley C, T. Full R.J., Koehl M.A., Kram R., Lehman S. (2000). How animals move: an integrative view. Eccentric exercise: mechanisms and effects when used as training regime or training adjunct. Science, 288, $100-106$.

Eriksson B.0., (1972). Physical Training Oxygen Supply and Muscle Metabolizmin 11-13 Years Old Boys, Acta Physiologica, Scandanavica. Suppl. 384.

Erkmen N., Suveren S., Göktepe A.S., Yazıcıoğlu K. (2007) The comparison of balance performance of the athletes who are in different branches. Spormetre Beden Egitimi Ve Spor Bilimleri Dergisi, V (3), 115-122.

Hammami R., Granacher U., Makhlouf I., Behm D.G., Chaouachi A. (2016) Sequencing effects of balance and plyometric training on physical performance in youth soccer athletes. The Journal of Strength and Conditioning Research, 30(12), 3278-3289. 
Harman E., Garhammer J. (2008). Administration, scoring, and interpretation of selected tests, In: Beachle TR, Earle RW, Eds. Essentials of Strength Training and Conditioning, 3rd Edition. Champaign, IL. Human Kinetics, s. 249-292.

Hazır T., Mahir Ö.F., Açıkada C. (2010). Genç futbolcularda çeviklik ile vücut kompozisyonu ve anaerobik güç arasındaki ilişki [The relationship among agility, body composition and anaerobic strength in young soccer players]. Spor Bilimleri Dergisi Hacettepe, 146-153.

Hindistan İ.E., Muratlı S., Özer M.K., Erman E.K. (1999). Egzantrik, konsantrik ve uzama kısalma döngülü kas çalışmaları ile yapılan kuvvet antrenmanlarının dikey sıçrama performansına etkisi [The Effect of Strength Trainings Applied with Eccentric, Concentric and Expanding-Shortening Cycle-based Muscle Practices on The Performance of Vertical Jump]. Beden Eğitimi ve Spor Bilimleri Dergisi (BESBD), 3 (2), 20

Işık A., Ünlü G. (2017). Spor yaralanmalarından korunmada teknoloji turkiye klinikleri [Technology in protecting from sports-based injuries: clinics in Turkey] Journal of Sports Medicine-Special Topics, 3(3).

Johnston W., O’Reillya M.F., Coughlanc G., Caulfielda B. (2017). Inertial sensor technology can capture changes in dynamic balance control during the y balance test, Digit Biomark, 1,106-117

Karacabey K. (2013). Sport performance and agility tests. International Journal of Human Sciences, 10(1), 16931704.

Kayıtken B., Yücel S.B., Dinç N. (2012). Benzer Şiddet Düzeyindeki Egzersizlerde Farklı Kas Katılım Modellerinin Fizyolojik Parametrelere Olan Etkileri [The Effect of Different Muscle Participation Models in Similar Level Exercises on Physiological Parameters]. Spor Bilimleri Dergisi Hacettepe Journal of Sport Sciences, $77-88$.

LaStayo P.C., Woolf J.M., Lewek M.D., Snyder-Mackler L., Reich T., Lindstedt S.L. (2003). Eccentric muscle contractions: their contribution to injury, prevention, rehabilitation, and sport. J Orthop Sports Phys Ther, 33, 557571

Lindstedt SL, LaStayo PC, Reich TE. (2001). When active muscles lengthen: properties and consequences of eccentric contractions. News Physiol Sci, 16, 256-261

Malisoux L., Francaux M. Nielens H. (2006). Stretch-shortening cycle exercises: an effective training paradigm to enhance power output of human single muscle fibers. J Appl Physiol, 100, 771-780.

Meylan C., Malatesta D. (2009). Effects of in-season plyometric training within soccer practice on explosive actions of young players, The Journal of Strength \& Conditioning Research, 23(9), 2605-2613.

Muratlı S. (2003). 'Çocuk ve Spor - Antrenman Bilimi Yaklaşımıyla', Nobel Basımevi, 1. Baskı, 201-219, Ankara, Temmuz.

Özer DS, Özer K. Çocuklarda Motor Gelişim. Ankara. Nobel Dağıtım. 2007; 198; 7-225

Plisky P. J., Rauh M. J., Kaminski T. W., Underwood F. B. (2006). Star Excursion Balance Test as a predictor of lower extremity injury in high school basketball players. Journal of Orthopaedic \& Sports Physical Therapy, 36(12), 911-919.

Proske, U., Morgan, D.L. (2001) Muscle damage from eccentric exercise: mechanism, mechanical signs, adaptation and clinical applications. J Physiol, 537(2), 333-345. 
Rosch D., Hodgson R., Peterson T.L., Graf-Baumannn T., Junge A., Chomiak J., Dvorak J. (2000). Assessment and evaluation of soccer performance. The American Journal of Sports Medicine, 29-39.

Schmidtbleicher D. (1992) Training for power events. in: the encyclopedia of sports medicine: strength and power in sport, edited by komi p. Oxford, UK: Blackwell, p. 169-179

Sevim Y. (2007). Antrenman Bilgisi [Training Studies]. Ankara: Nobel Yayınevi.

Soğat A. (2007). Spor Yapan ve Yapmayan 11-12 Yaş Grubu Çocuklarda Bazı Fiziksel Özelliklerin Araştırılması. Yayımlanmamış Yüksek Lisans Tezi, Dumlupınar Üniversitesi Sosyal Bilimler Enstitüsü, Kütahya

Şendil A. (2008). Dehidrate olmuş bireylerde step machine aletinde yapılan egzersize bağlı olarak oluşan gecikmiş kas ağrısı (DOMS) üzerine izotonik spor içeceklerinin etkisi [The effect of isotonic sports drinks in dehydrated individuals on delayed onset muscle soreness caused by the exercise done on step machine]. Ankara: Hacetttepe Üniversitesi Spor Bilimleri ve Teknolojileri.

Thomas K., French D., Hayes P. R. (2009). The effect of two plyometric training techniques on muscular power and agility in youth soccer players. The Journal of Strength \& Conditioning Research, 23(1), 332-335.

Turner A. (2011). Defining, developing and measuring agility. UK Strength and Conditioning Association, 22, 2628.

Vogt M., Hoppeler H.H. (2013). Eccentric exercise: mechanisms and effects when used as training regime or training adjunct, The American Physiological Society, First published February 6, 2014; doi:10.1152/japplphysiol.00146.2013.

Wilson G.J., Newton R.U., Murphy A.J., Humphries B.J. (1993). The optimal training load for the development of dynamic athletic performance. Med Sci Sports Exerc, 25, 1279-1286. 